University of Michigan Law School

University of Michigan Law School Scholarship Repository

\title{
If Taxpayers Can't Be Fooled, Maybe Congress Can: A Public Choice Perspective on the Tax Transition Debate
}

\author{
Kyle D. Logue \\ University of Michigan Law School, klogue@umich.edu
}

Available at: https://repository.law.umich.edu/reviews/110

Follow this and additional works at: https://repository.law.umich.edu/reviews

Part of the Law and Economics Commons, Law and Politics Commons, and the Tax Law Commons

\section{Recommended Citation}

Logue, Kyle D. "If Taxpayers Can't Be Fooled, Maybe Congress Can: A Public Choice Perspective on the Tax Transition Debate." Review of When Rules Change: An Economic and Political Analysis of Transition Relief and Retroactivity, by D. Shaviro. U. Chi. L. Rev. 67, no. 4 (2000): 1507-33.

This Review is brought to you for free and open access by the Faculty Scholarship at University of Michigan Law School Scholarship Repository. It has been accepted for inclusion in Reviews by an authorized administrator of University of Michigan Law School Scholarship Repository. For more information, please contact mlaw.repository@umich.edu. 


\title{
If Taxpayers Can’t Be Fooled, Maybe Congress Can: A Public Choice Perspective on the Tax Transition Debate
}

\author{
Kyle D. Logue $\dagger$
}

\begin{abstract}
When Rules Change:An Economic and Political Analysis of Transition Relief and Retroactivity. Daniel Shaviro. University of Chicago Press, 2000. Pp xiii, 253.
\end{abstract}

\section{INTRODUCTION}

It is a truism that changes in government policy can produce losers and winners. And nowhere is that truism more clearly revealed, or more closely studied, than in the context of tax rule changes. Consider the individual who makes an investment in real estate or business equipment or some sort of financial instrument (such as stocks or bonds) or even in human capital, and who does so in reliance on a special tax deduction or credit which applies to that investment. If the relied-upon tax preference is unexpectedly repealed, the investor may suffer what is sometimes called a "transition loss," a decline in the value of the pretransition investment.

The story can just as easily go the other way: if an individual makes an investment before the enactment of the special deduction or credit (and oblivious to the possibility of its enactment), she may enjoy a windfall "transition gain" when the new rule is unexpectedly adopted. And both effects-transition losses and gains-can result from any number of tax rule changes (including changes in the tax base as well as in tax rates) as well as from non-tax-law policy changes of every variety, ranging from developments in common law tort doctrine to changes in environmental laws or regulations to changes in government spending programs.

That unexpected rule changes produce losers and winners is uncontroversial. Disagreement arises over the question of what, if anything, should be done about these transition effects. To put the question slightly differently, what should our "transition policy" be? Or put differently still, to what extent should the government deliberately try to alleviate the "retroactive" effects of rule changes?

$\dagger$ Professor of Law, University of Michigan Law School. I am grateful for comments received from Steve Croley, Saul Levmore, and Daniel Shaviro. All remaining errors are my own.

1 The concept of retroactivity can be defined in many different ways, and the definition 
However you put it, the question has spawned a substantial literature, which can be understood as having developed in three general phases (pp 2-3). Phase one was the "old view" scholarship, which relied on general fairness concerns to argue against uncompensated retroactive rule changes. In phase two, applying the assumptions and methods of modern economics (and the policy goal of social welfare maximization), "new view" scholars offered a decidedly more favorable take on retroactivity, and hence less favorable view of transition relief Phase three marked something of a revival of the old view (or a reaction to the new view) in which scholars mounted welfarist (socialwelfare maximization) defenses of transition relief in certain contexts. In addition, and somewhat separately, a number of tax policy scholars have for years encouraged the use of retroactive taxation precisely because such taxes have the capacity to surprise investors and thus to raise revenue without distorting incentives.

And now Professor Daniel Shaviro, building on the new view approach but adding his own distinctive spin, has written what will likely be considered the definitive study of legal transitions from the utilitarian or welfarist perspective, ${ }^{2}$ and perhaps from any perspective. In When Rules Change: An Economic and Political Analysis of Transition Relief and Retroactivity, Shaviro takes the various strands of the existing literature on retroactivity and weaves them together, applying his unique combination of legal expertise, political pragmatism, and theoretical sophistication in public finance economics as well as political science. The result is a subtle, balanced, and scholarly treatise on transition relief and retroactivity that should serve as the starting point for all future research in the field.

In its stated objectives, the book is admirably ambitious. As Shaviro puts it in the introduction,

This book seeks to reframe the scholarly transition debate, and possibly even influence political practice, through two distinct contributions. The first is to advance economic understanding of

that a particular scholar has in mind can be crucial to his or her transition policy recommendation. For now, it is enough to understand that there are degrees of retroactivity; that is, a new rule can be applied more or less retroactively. See Saul Levmore, The Case for Retroactive Taxation, 22 J Legal Stud 265, 266-72 (1993). More precise definitions will be offered as the Review unfolds.

2 Shaviro explicitly adopts the "social welfare norm of utilitarianism, which seeks to maximize social welfare" ( $p$ 16). I will therefore use the term "welfarist" to describe Shaviro's approach to transition issues. For a precise account of Shaviro's normative assumptions, see pp 16-19. For a comprehensive defense of social welfare maximization as the appropriate norm for evaluating public policy, see Louis Kaplow and Steven Shavell, Principles of Fairness Versus Human Welfare: On the Evaluation of Legal Policy, John M. Olin Center for Law, Economics, and Business, Harvard Law School, Working Paper No 277 (Mar 2000), available online at $<$ http://www.law.harvard.edu/programs/olin_center/> (visited May 12, 2000). 
the transition issues posed by rule changes generally, albeit with particular reference to issues in the federal income tax. The second is to integrate the economics with a political science analysis that is distinctive to the present federal income tax system, in order to propose norms that should generally guide transition practice in this area (pp 1-2).

Are these ambitious goals achieved? Remarkably, to a large extent they are. For example, Shaviro advances the "economic understanding" of transition issues in a number of different ways, perhaps most significantly in his sustained argument against the use of surprise retroactive taxation as a nondistortionary source of revenue and in his introduction of a new taxonomy of rule changes.

However, it is with respect to the book's second stated objective ("to integrate the economics with a political science analysis that is distinctive to the present federal income tax") (p 2) that Shaviro's most imaginative contributions come. For example, he develops and applies a public choice perspective to the tax transitions question, a perspective that includes a refreshingly realistic (if somewhat cynical) assessment of the tax lawmaking process. In addition, he makes bold and potentially controversial use of the "widespread consensus among tax policy thinkers" that the welfare-maximizing tax system is one that approaches the comprehensive tax base ("CTB") ideal by doing away with all (or almost all) tax preferences ( $\mathrm{p} 93$ ).

Although Shaviro's framework is cleverly conceived and defended, the "concrete policy payoff" it generates is something of a disappoinment ( $p$ 14). After making a great show of the extent to which the new view transitions framework fails to incorporate the reality of political decisionmaking, Shaviro ends up adopting a version of the new view recommendations, albeit on different grounds ( $p$ 229). The reason for this anticlimactic conclusion, however, lies not with a lack of nuance or subtlety in Shaviro's analysis. It is difficult to imagine a more nuanced and subtle analysis. Rather, the reason lies in the nature of the transition problem, especially in the tax-legislative context, as well as a curious characteristic of public-choice-oriented normative tax policy scholarship.

This Review will, in a broad sense, follow Shaviro's characterization of the book's objectives. Part I will summarize the existing economic framework for analyzing legal transitions and retroactivity issues (with major emphasis on tax transitions). Although Shaviro makes numerous interesting contributions to this framework, this Review will examine only the two most significant of these. That will be done in Part II. Then, Part III will focus on Shaviro's principal innovation: his introduction of a thoroughgoing public choice perspective and CTB ideology to the tax transitions debate. 


\section{THE EXISTING ECONOMICFRAMEWORK ${ }^{3}$}

\section{A. Choosing the Optimal Transition Policy}

What is a "transition policy" anyway? The idea is to exert some influence over the decisions of political actors, to affect how they decide to implement new rules. Shaviro provides the best articulation of this idea in his concept of a "constitutional norm." As Shaviro points out, a constitutional transition norm need not be, and usually is not, legally binding on the political decisionmakers in question-the ones who are making the policy changes to which the norm will apply. But a transition norm, to be effective, must at least be a "stable long-term rule or aspiration" that is somewhat "binding," at least in the sense of constraining or influencing the behavior of government actors (p 92). ${ }^{4}$ Thus, in the legislative context, the transition policy would be the prevailing norm, whether implicit or explicit, that tends to govern ("influence") legislators' decisions as to how transition losses and gains will be handled in the event of rule changes.

The next question is the one to which normative transition scholarship has largely been addressed: What should our transition norm be? And should it be different in different contexts? Before economic analysis was applied to that question, normative scholarship on the subject tended to focus on the "reasonable expectations" of investors and on the unfairness of making rule changes apply to those who had relied on prior law. Thus, the traditional view (again, sometimes called the old view) disapproved of retroactivity generally, especially in the legislative context. Economic analysis changed the terms of the discussion and reversed the presumption, introducing a generally more favorable view of retroactivity and less favorable view of transition relief.

By far, the most comprehensive statement of the existing (preShaviro) economic framework for analyzing legal transitions can be

3 Because of space constraints, this summary will be highly abridged. For a full review of the economic literature on transition issues, see Saul Levmore, Retroactive Taxation, 3 New Palgrave Dictionary of Economics and the Law 340 (MacMillan 1998); Louis Kaplow, An Economic Analysis of Legal Transitions, 99 Harv L Rev 511 (1986); and the Shaviro book itself.

4 It is in this sense that transition scholars often speak of a government's "binding commitment" or "precommitment" to follow a particular transition policy. See, for example, Kyle D. Logue, Tax Transitions, Opportunistic Retroactivity, and the Benefits of Government Precommitment, 94 Mich L Rev 1129, 1140, 1148, 1157 (1996).

5 One of the principal contributions of Shaviro's book is to summarize the existing tax transition norms that appear to be currently in effect with respect to certain types of tax law changes (pp 98-110).

6 See, for example, Stephen R. Munzer, Retroactive Law, 6 J Legal Stud 373, 391 (1977); Charles B. Hochman, The Supreme Court and the Constitutionality of Retroactive Legislation, 73 Harv L Rev 692, 692-93 (1960). 
found in a 1986 article by Louis Kaplow.' According to that framework, the choice of an efficient transition policy turns, at least initially, on two general questions: First, what transition norm would optimally allocate the risk of a change in government policy, that is, the risk of ransition losses and transition gains? And, second, what transition norm would give investors the optimal incentives concerning whether and how much to rely on any govermment policy?

\section{B. The New View: Focusing on Risk Incentives}

Standard economic analysis generally assumes that individual investors dislike risk, all else being equal. How do we know this? Investors regularly buy insurance policies or diversify their stock portfolios as ways of reducing the variance of outcomes that they face. Just as investors appear to want to shed themselves of such market-created risks, presumably they would like to do the same with governmentcreated risks, such as the risk of experiencing an unexpected transition loss or gain caused by a change in government policy. A number of scholars have observed this equivalence. ${ }^{8}$ And it is an observation that carries some weight, because it is also generally assumed that private investors should be responsible for finding their own ways to deal with market-created risks. Thus, if there is a general equivalence between market-created risk and govermment-created risk, the starting assumption should be the same: private parties should be expected to find ways (through insurance policies or portfolio diversification or whatever) of dealing with the risk of uncompensated changes in government policy that would accompany a retroactivity norm.

But perhaps there is something different about ransition risk. Perhaps there is some reason why, with respect to govemment-created risk, private markets working alone are not sufficient. The economic framework, primarily in Kaplow's article, looks at this question and concludes that, in fact, the market-risk/govermment-risk equivalence generally holds. Specifically, part of Kaplow's analysis is devoted to working through a number of reasons why we generally expect private insurance mechanisms to be more effective than governmentprovided insurance at dealing with the standard insurance inefficien-

7 See Kaplow, 99 Harv L Rev at 520-66 (cited in note 3). Although the Kaplow article provides the most comprehensive statement of the economic framework for analyzing legal transitions, the article does not reach definitive conclusions as to what the welfare-maximizing transition policy would be for any particular type of rule change.

8 See id at 533-36; Michael J. Graetz, Legal Transitions: The Case of Retroactivity in Income Tax Revision, 126 U Pa L Rev 47, 65 (1977); Martin Feldstein, On the Theory of Tax Reforn, $6 \mathrm{~J}$ Pub Econ 77, $92-93$ (1976).

9 See Kaplow, 99 Harv L Rev at 513-14,520, 527-36 (cited in note 3); Graetz, 126 U Pa L Rev at 65 (cited in note 8). 
cies caused by the asymmetrical information between insurer and insured; that is, the problems of moral hazard and adverse selection. And he explains why those problems are present with respect to transition risk as well, an assessment with which Shaviro appears to agree.

The implication of this analysis is that any risk-allocation defense of an anti-retroactivity norm-or a norm favoring transition reliefcan largely be ignored. Since we can count on investors to deal with transition risk on their own, our transition norm need not be concerned with it. That conclusion seems to have gained considerable sway in the literature." Indeed, even Shaviro asserts that "the transition risk analysis often lacks significant policy implications" (p 42).

In addition to worrying about optimal risk allocation (at least long enough to dismiss it), the standard economic analysis of legal transitions is concerned with giving private parties the incentive to anticipate rule changes. And this concern is not dismissed. The basic argument is straightforward: a transition policy that credibly promises not to alleviate the retroactivity effects of rule changes will encourage investors to take into account the possibility of such changes-even to anticipate them. And this will generally be a good thing, if we assume that government policy, over time, will tend toward the maximization of social welfare. ${ }^{13}$

Although the best example of the welfare-enhancing incentive effect of a retroactivity transition norm is that of a product ban (which, if made retroactive, gives manufacturers the incentive to pursue optimal safety for pretransition as well as post-transition production), it is

10 See Kaplow, 99 Harv L Rev at 540-42 (cited in note 3). Shaviro seems to agree with this conclusion at $\mathrm{p} 42$.

11 For example, in none of his work on retroactivity does Saul Levmore discuss the riskallocation question. He focuses instead exclusively on the incentive dimension of the transition issue, which is discussed in the next section. See Saul Levmore, Changes, Anticipations, and Reparations, 99 Colum L Rev 1657, 1661-86 (1999); Levmore, Retroactive Taxation at 340 (cited in note 3); Levmore, $22 \mathrm{~J}$ Legal Stud at 279-91 (cited in note 1). Furthermore, I am aware of no article or book that explores the government-risk question, as Kaplow poses it, in any level of detail. Therefore, Shaviro's conclusion that the significance of the transition risk issue "has mainly been exaggerated" is puzzling ( $\mathrm{p} 42$ ).

12 Both Kaplow and Shaviro, however, mention a possible exception to this dismissal of transition risk concerns. Specifically, they note that, in situations in which extremely lowprobability events are systematically underestimated by individuals, those individuals may tend to underinsure, with potentially drastic consequences if the event comes to pass. Kaplow, 99 Harv L Rev at 602-03 (cited in note 3); Shaviro (pp 33-42).

13 Put differently, if we believe that good policy changes will in the long run outweigh bad ones, a rule that generally induces behavioral changes by investors in anticipation of rule changes will likewise enhance social welfare. This idea was first emphasized in a classic tax article by Michael Graetz and was later built into the larger economic framework by Kaplow. See Graetz, 126 U Pa L Rev at 65-66 (cited in note 8); Kaplow, 99 Harv L Rev at 533 n 65 (cited in note 3) (quoting Graetz). When Shaviro refers to this idea, he too calls it the "new view," and he cites Graetz as the originator (pp 43,64,101). 
not the only one, not by a long shot. Indeed, part of what makes the incentives analysis so appealing, and controversial, is the strikingly broad range of rule changes to which it can be applied. Thus, the same welfare-enhancing incentive aspect of a retroactivity norm exists with respect to many types of rule changes, including, but not limited to: a judicial decision expanding (in an efficiency-enhancing way) tort liability for product-caused accidents; the repeal of a special tax preference provision that (for whatever reason) has proved to be a bad idea; or even the taking of private property for public use. In each of these cases, so long as one assumes that the government (including the legislative, executive, and judicial branches) is generally moving in the right (welfare-enhancing) direction over time, the new view incentives analysis would apply. ${ }^{14}$

\section{The Old View Revisited: Incentive Subsidies and Opportunistic Retroactivity}

It was to this basic new view economic framework (and explicitly conditioned on its assumptions) that I made a small contribution in an article published in $1996 .^{15}$ In that article, I offered an efficiency-based justification for providing transition relief with respect to a specific category of rules. My argument was that, if there is an identifiable category of rules that the government uses as a means of inducing specific reliance by investors and that we want to preserve for the government's future use (a category of rules that I call "incentive subsidies"), then adopting a transition policy that permits the imposition of transition losses upon repeal of such rules would come at a cost.

The problem is this: investors, knowing of such a transition policy, would demand a larger subsidy than if the ransition policy forbade retroactive repeal. I call this the "default-premium effect." Indeed, at the limit, if the retroactivity norm were sufficiently extreme-if the norm essentially said that whatever incentive subsidy the government provides will be opportunistically confiscated ex post (through nominal retroactivity or outright theft if necessary), then inducing reliance on the government's incentive subsidies would become impossible.

Given my adoption of the new view assumption of a benevolent, long run, social-welfare-maximizing government, one might ask why the concern for government opportunism. Can a benevolent government engage in theft? In fact, from a purely welfarist perspective, a

14 As will be discussed more fully in Part III.A below, Shaviro observes that there may be categories of rule changes for which the desirability of this anticipatory incentive effect will not hold.

15 See Logue, 94 Mich L Rev at 1129 (cited in note 4).

16 Id at 1140. 
certain sort of government opportunism is entirely consistent with the benevolent-government assumption. According to the literature on the so-called "time-inconsistency" problem, developed by scholars within the rational-expectations school of macroeconomic theory, an otherwise social-welfare-maximizing government will behave opportunistically (will become a wealth expropriator) if (a) it cannot make binding promises not to do so, and (b) despite this fact, investors have no clue that the government would ever do such a dastardly thing." Under those assumptions, it can be shown that a policy plan of promising not to enact opportunistic expropriative retroactive rule changes, and then promptly tuming around and doing just that, is in fact "optimal." ${ }^{18}$

The lesson of rational-expectations theory, however, is that such a policy plan, though optimal if it were to succeed, cannot in fact possibly succeed. Investors are not that stupid. They will anticipate such opportunism, perhaps even before they have been burned once but certainly afterward. And the government's bait-and-switch plan will break down over time. In fact, the certainty of its long run breakdown will feed back into the original decision by the government to adopt the plan in the first place. In other words, once rational expectations are taken into account, such an optimal plan is said to be "timeinconsistent." ${ }^{19}$ A nonstarter.

The default-premium effect that I have associated with the retroactive repeal of incentive subsidies is analogous to this timeinconsistency problem. ${ }^{20}$ Fearing expropriative retroactive repeal, investors will demand a default premium in their incentive subsidies, or may not be willing to rely on them at all. Thus, according to my analysis, the welfare-maximizing transition norm with respect to incentive subsidies may be one that forbids (or at least discourages) the govermment from opportunistically expropriating previously provided incentive subsidies. That norm, in other words, may include an implicit precommitment (again, a constitutional norm) that the legislature will provide some minimal level of transition relief should a given class of incentive subsidies be repealed.

Notice I said "may." Whether such a special ransition norm for incentive subsidies would in fact be welfare enhancing depends on a

17 The classic article on the subject is Finn E. Kydland and Edward C. Prescott, Rules Rather than Discretion: The Inconsistency of Optimal Plans, $85 \mathrm{~J}$ Pol Econ 473, 474-75 (1977). Shaviro ref ers to this literature and the idea of opportunistic "rent extraction" briefly (p 89).

18 That such an outcome could conceivably be called "optimal" is what drives some scholars to doubt the welfarist approach.

19 See, for example, Stanley Fischer, Dynamic Inconsistency, Cooperation and the Benevolent Dissembling Government, 2 J Econ Dynamics \& Control 93, 94, 98 (1980) (demonstrating the benefits of credible government precommitment to optimal tax policy plan).

20 See Logue, 94 Mich L Rev at 1143 n 54 (cited in note 4). 
series of difficult conceptual and empirical questions. For starters, how does this old view goal of encouraging taxpayer reliance on certain government actions balance out against the new view goal of encouraging investors to anticipate rule changes? The answer may depend on our confidence in the initial decision to use the incentive subsidy in the first place and in our assessment of the likely need to use such incentive subsidies in the future. ${ }^{21}$

Another objection that I have heard to my time-inconsistency/ default-premium argument runs as follows: when the government needs to make a binding commitment to induce specific acts of reliance on the part of investors, it should do so through the use of a legal contract, and only through the use of a legal contract. That is, after all, what government contracts are for: to allow the government to make binding promises about how much it will pay, to whom, and for what. Incentive subsidies, especially in the form of tax preferences, should never be used in that way. Rather, the argument goes, with any type of policy tool besides a government contract, no government commitment should be made as to whether payment will be forthcoming. To put the argument in quintessentially new view terms, with respect to such incentive subsidies, it is better to put investors on notice that such tax preferences, like any other law, can change in any way imaginable, including nominally retroactively, and at any time so that investors adjust their expectations accordingly and take steps to anticipate changes.

In response to this objection, I can only fall back on my own intuition, since a definitive resolution of the issue must await empirical investigation. And my intuition is this: if we believe that the government should be able to make somewhat binding precommitments with respect to its contractual arrangements, ${ }^{2}$ it is likely that the government should also be able to make precommitments (albeit only implicit ones and only binding in the sense in which Shaviro talks of the

21 For example, as will be discussed more fully in Part III.C below, Shaviro makes an argument that suggests that, for public choice reasons, we should adopt a transition policy that discourages the use of all (or almost all) tax preferences ( $p$ 98). If one takes that argument seriously, the threat of opportunistic retroactive repeal of such provisions might be just the ticket. How far Shaviro wants to push the argument is unclear.

22 How "binding" we want even government contracts to be is something of an open question, for the same sort of public choice reasons that (as Shaviro emphasizes) we should be cautious about "guaranteeing" tax preferences. For recent public choice oriented arguments that government contracts should be considered less binding on the government than private contracts are on private parties, see, for example, Gillian Hadfield, Of Sovereignty and Contract: Damages for Breach of Contract by Government, 8 S Cal Interdiscipl L J 467, 469 (1999); Daniel R. Fischel and Alan O. Sykes, Governmental Liability for Breach of Contract, 1 Am L \& Econ $\operatorname{Rev} 313,327-32$ (1999). Even these scholars, however, assume that government contracts will be binding to some extent. See Hadfield, $8 \mathrm{~S} \mathrm{Cal} \mathrm{Interdiscipl} \mathrm{L} \mathrm{J} \mathrm{at} 469$ (proposing to analyze, not if, but how the government is bound). 
binding effects of "constitutional" norms) in some other settings in which specific investor reliance is needed but entering into individual contracts with investors is not practical. For example, it would presumably be extremely difficult to use a series of direct government contracts to replicate the type of broad-based reliance effect that a tax credit or tax deduction can induce-that is, reliance on the part of many investors in many parts of the country with relatively little in the way of red tape and other transaction costs. ${ }^{23}$ Thus, if government contracts should be considered binding, perhaps incentive tax provisions should be treated similarly, as being accompanied by an implicit precommitment to provide transition protection in the event of repeal. ${ }^{24}$

In some respects, Shaviro seems to agree with my defaultpremium concern. For example, in his discussion of the transition-risk analysis, with a concept he calls "transaction flexibility," Shaviro captures the core of my precommitment idea (pp 37-40). He suggests that, where individually negotiated government contracts are impractical, the government might "offer the same rule in a variety of 'flavors,' which differ only in the details of their transitional guarantees" (p 38).

\section{When Surprising Investors Is the Whole Point}

The final element of the existing economic framework for analyzing legal transitions is the idea of the ex post capital levy. Among economists, it is sometimes argued that certain types of retroactive taxes are desirable precisely because they are a surprise to investorsthat is, precisely because they are not anticipated and have little or no effect on taxpayers' incentives. ${ }^{26}$ The argument derives from the optimal-tax literature, which defines an optimal tax as one that produces the least possible distortion of taxpayer or investor decisions-specifically, the least possible effect on the labor-leisure tradeoff. ${ }^{27}$

According to the optimal-tax perspective, then, the best tax is one that the taxpayer can or will do nothing or very little to avoid. Such a tax is sometimes referred to as a lump-sum tax. The head tax would be

23 See Logue, 94 Mich L Rev at 1144 (cited in note 4).

24 And let me be clear: I do not mean that contract law should be applied to tax preferences. Taxpayers should not be able to haul Congress into court for repealing an incentive subsidy without providing transition relief. Rather, my argument is that there should be-and, as will be discussed in Part III.C below, there probably already is-a norm in Congress that constrains such retroactive repeal.

25 There he was discussing the options of indexed versus unindexed government bonds, but later he notes that "this practice of offering the same rule in multiple 'flavors' could be extended to other contexts," including tax preferences (p 39).

26 See, for example, Levmore, 22 J Legal Stud at 273-78 (cited in note 1).

27 See James A. Mirrlees, An Exploration in the Theory of Optimum Income Taxation, 38 Rev Econ Stud 175, 175-76 (1971). 
one example: each individual taxpayer pays the same amount of tax. Period. The problem is that a head tax is regarded as distributively unjust. So are many other quasi-optimal taxes, such as excise taxes on inelastically demanded consumer products. In part for that reason, we have chosen at least at the federal level to rely primarily on income and wage taxes. But taxing income or wages means also introducing some distortion, as people can choose to earn less, substituting leisure for work.

Enter the surprise retroactive tax. If the new tax is genuinely a surprise to taxpayers, then, by definition, they can do nothing to avoid it. And the bigger the surprise, the better. Plus, it is possible to make a retroactive tax somewhat progressive by making the tax base something that correlates with current income or wealth, say, past income or wealth. Thus, for one example, Saul Levmore notes the potential optimal-tax benefits of applying a tax rate increase or tax deduction repeal nominally retroactively, to tax years prior to the year of enactment. $^{28}$

As was already discussed above in connection with the defaultpremium effect, the problem with trying to surprise taxpayers with a retroactive tax, from an incentives perspective, is that taxpayers are not easily fooled that way. ${ }^{2 x}$ If there is a transition policy in effect that permits the adoption of nominally retroactive income tax rate increases, or of ungrandfathered wealth-tax increases, such a policy will eventually be found out; the news will work its way down to the masses, leading to just the sort of anticipatory behavioral effects that optimal-tax theory tells us to avoid. Again, this is the lesson of the rational-expectations approach. ${ }^{30}$

\section{SHAVIRO'S SPIN ON THE EXISTING ECONOMIC FRAMEWORK}

\section{A. Taking Rational Expectations Seriously: Surprise Taxation Can Never Work}

One of Shaviro's most important contributions to the existing economic framework is his comprehensive and sustained attack on the optimal-tax justification for surprise retroactive taxes. In Shaviro's view, the findings of the rational-expectations literature, mentioned above, justify a somewhat extreme and potentially controversial con-

28 See Levmore, 22 J Legal Stud at 274 (cited in note 1).

29 Levmore discusses this possibility. See id at 274,276 . One of his responses is that even a little surprise is better than none. See id. My retort was this: "True enough. However, having been hit once with a 'bolt from the blue,' and knowing that Congress will be tempted to try the same trick again, taxpayers will begin to watch the sky for the next one."Logue, 94 Mich L Rev at 1172 n 140 (cited in note 4).

30 See Logue, 94 Mich L Rev at 1172 n 140 (cited in note 4) ("This is the quintessential example of the time-consistency problem."). 
clusion: that the use of surprise taxes can never have long-run efficiency benefits.

In developing this position, Shaviro points out that rationalexpectations theory does not claim that investors will never be surprised by rule changes. Of course, they will. Rather, the claim is somewhat more modest: given that individuals will learn from experience, we should assume that they will not be fooled by a program of surprise macroeconomic policy changes, at least not in a systematic way. That is, even if some investors are fooled, there is no obvious direction that the errors will tend to take. Some will underestimate the likelihood of the policy change; others will overestimate it. In any event, the under- and overestimation errors will cancel each other out, thereby canceling out the lump-sum benefits of a long-term program of surprise policy changes.

From these seemingly modest premises, Shaviro concludes that the analysis of transition issues should proceed on the assumption that it is impossible ever to fool investors systematically in the long run." Moreover, although Shaviro acknowledges the possibility that cognitive biases on the part of individual investors (such as systematic underestimation of retroactive policy changes) could in theory undermine his strong rational-expectations presumption (pp 22-25), ${ }^{32}$ he ultimately dismisses that possibility.

Thus, we are left with Shaviro's operating assumption: that a program of surprise retroactive taxation cannot in the long run have optimal-tax benefits. ${ }^{34}$ But what about something short of a "program" of surprise taxes? What about the possibility of using this policy tool only

31 "Rational expectations suggests that, if one is thinking about the long run, the incentive effects of retroactive rule changes can fruitfully be analyzed by ignoring their retroactivity and treating them instead as if they were preannounced or otherwise fully anticipated" ( $p 22)$.

32 Where Shaviro reviews conclusions from the fields of cognitive psychology and behavioral or "quasi-rational economics."

33 Specifically, he argues that, until advocates of surprise retroactive taxation can offer empirical evidence that there is a specific cognitive bias that systematically distorts investors' perceptions of the likelihood of future retroactive taxes, we should assume that surprise retroactive taxation cannot be used successfully as a lump sum tax ( $p 25)$. Of course, determining which side in a debate bears the burden of empirical proof will often determine the winner of the debate. In Shaviro's defense, however, he has offered something more. He has presented the conclusions of the rational-expectations literature, a literature, according to Shaviro, whose empirical findings strongly confirm its hypothesis: that investors cannot generally be fooled systematically by a program of surprise policy changes. Although Shaviro notes that the "full-fledged rational expectations approach ... has not entirely carried the day" in the macroeconomics literature, he implies that the remaining nonbelievers are merely suffering from an insufficiently long-run perspective ( $p 21$ ). ("Rational expectations still holds over a longer term, however" ( $p 21)$.) Whether he is right about that conclusion I do not know.

34 This conclusion seems somewhat in tension with his willingness, elsewhere in the book, to entertain the possibility that individual investors may systematically underestimate the "risk" of uncompensated policy changes ( $p 40)$. 
on rare, exceptional occasions-such as when we finally (once and for all) manage to shift from the current income-based tax to something closer to a consumption-based tax? Maybe that would be a good occasion for a onetime-only wealth tax, a capital levy accompanied by a promise never to do anything like that again, at least not anytime soon.

Shaviro heaps scom on this idea, and perhaps rightly so. The problem with the "just this once" approach, of course, is that the government's very use of the retroactive tax may well undermine the credibility of the promise not to repeat the trick. ${ }^{35}$ To the contrary, it might have the perverse effect of alerting investors to the possibility of retroactive taxation, a possibility that many of them may never have considered before. ${ }^{36}$ Thus, in Shaviro's words: "Today's 'surprise party' may therefore prompt tomorrow's 'surprise non-party,' resulting in compensating errors in anticipation of retroactive change that prevent the government from using surprise to its advantage on balance" (p 22).

He may be right about that as well. But then again, he may not. To the best of my knowledge, the precise findings of the rationalexpectations literature do not speak directly to the question at hand: that is, would it be possible for Congress, at the time it enacts a surprise retroactive tax, to make a credible commitment not to do so again for a sufficiently long period of time that the incentive effect would be trivial? In fact, we do not have any empirical evidence, one way or the other, on that question. Given this situation of profound uncertainty, what should our conclusion be?

If Shaviro's position on surprise taxation represents one extreme answer to that question, presumably the other extreme-the view that surprise taxes could be used effectively on a regular basis-has few adherents. An interesting question is what about the middle ground? That is, given the absence of empirical studies demonstrating specific cognitive biases on the part of investors with respect to retroactive taxes (and given that such studies may not be forthcoming anytime soon), should we consider an "only occasionally" or "just this once" retroactive tax strategy in the meantime? I, for one, find the possibility of a just-this-once retroactive tax somewhat attractive, although I obviously see the dangers that such a strategy would entail. ${ }^{37}$

35 See Logue,94 Mich L Rev at 1172 (cited in note 4).

36 See id. "What's more, taxpayers may be less likely to believe Congress's commitment if it comes on the heels of the first surprise retroactive tax." Id. "Moreover, given the salience of the first retroactive tax, taxpayers may have a tendency to overestimate the chance of its reoccurrence." Id at 1172 n 140.

37 As I noted above, perhaps the just-this-once promise would be somewhat credible if the retroactive tax is enacted as part of a presumably onetime-only shift from an income tax to a 


\section{B. Developing the Policy Change/Accounting Change Distinction}

The other major contribution that Shaviro makes to the existing transitions framework is the addition of a taxonomy for classifying rule changes. The most important aspect of this taxonomy-the one that he uses throughout the remainder of the book-is the distinction between the "policy content" and the "accounting content" of rules. According to Shaviro's taxonomy, every tax rule can be divided into its policy content (the efficiency and distributional aspect of the rule) and its accounting content (the details of the rule's implementation "that could in principle be changed without affecting its policy content") (pp 53-54). Shaviro uses these ideas to distinguish between "policy change" retroactivity and "accounting change" retroactivity.

Policy change retroactivity arises in situations in which the anticipatory (new view) incentive effects of retroactivity would be desirable if and only if the rule change itself is desirable. ${ }^{33}$ Thus, the merits of retroactivity in such cases depend on the "steady-state merits" of the new rule itself ( $p$ 48). By contrast, accounting change retroactivity arises in situations in which anticipatory incentive effects would be bad, and should be discouraged, even if the rule change itself is good - that is, regardless of the new rule's steady-state merits ( $p 50$ ).

To exemplify policy change retroactivity, Shaviro offers the standard product ban example. In addition, he mentions the example of the repeal of the tax exemption for municipal bond interest. In both cases, whether making the repeal retroactive (applicable to pretransition investments) will have beneficial incentive effects depends on the efficiency of the incentive effects that the new rules themselves are expected to have. Thus, if we think the product ban and the elimination of the bond exemption will improve incentives - that is, if we think the government has made social-welfare-increasing decisions by adopting those rules, then making those decisions retroactive will induce efficient behavioral responses for pretransition investments as well. And if we think the rule changes are bad, retroactivity would likewise be bad ( $p$ 48).

The starkest example of accounting change retroactivity is the hypothetical shift from a tax-accounting year that is based on the calendar year (ending, of course, on December 31) to one that is based on a fiscal year (ending on June 30). Absent some sort of deliberate transition relief, such as the introduction of a special onetime short ac-

\footnotetext{
consumption tax.

38 And here we must again be careful in defining retroactivity. In general, when Shaviro uses the term retroactivity-such as with his idea of a "policy change retroactive tax"-he means something like nominal prospectivity without grandfathering. When he means nominal retroactivity, which he thinks is and should be discouraged, he uses that term explicitly, and so will I.
} 
counting year, some income may be taxed exactly twice in the transition year, and some may escape tax entirely ( $p 50) .^{39}$ The reason this example is so powerful, and why Shaviro's ultimate conclusion that an antiretroactivity norm should apply to such cases, is that there is no apparent (or even conceivable) policy justification for such a random result. That is, one cannot easily imagine what beneficial anticipatory behavior a retroactivity norm could have in such a case.

The utility of the policy change/accounting change distinction, however, will depend ultimately not on its application in the obvious case, such as the accounting rule change, but in the more difficult cases. To take perhaps the most important example in Shaviro's book, consider the accounting change and policy change aspects of proposals to shift from our current income tax to a more consumption-based tax regime (ch 9). Shaviro rightly, and skillfully, elucidates a number of ways that several leading consumption-tax proposals conflate an array of tax-rule changes that can usefully be disaggregated into various policy change aspects and accounting change aspects (pp 181-95).

For example, Shaviro notes that the essential difference between an income tax and a consumption tax is the treatment of the "return to waiting." Thus, if we imagine two households with the same wage flows over time, "the income tax imposes a higher tax burden on the later than the sooner consumer, whereas the consumption tax imposes the same tax burden, in present value terms, on each" (p 171). Thus, the policy aspect of shifting from an income tax to a consumption tax would amount to a decision to exempt the retum to waiting. In Shaviro's taxonomy, therefore, whether that particular change should be made retroactive (that is, whether retroactivity would have desirable anticipatory incentive effects) depends on the desirability of the consumption tax idea itself, the idea of exempting the return to waiting. (For example, if we think that taxpayers are saving too little, and that a consumption tax will tend to encourage more savings, making the move to a consumption tax retroactive might induce desirable anticipatory savings decisions.)

Most major consumption tax proposals, however, also include a number of accounting changes as well, which are not clearly identified as such (p 184). Admirably picking on someone his own size, Shaviro cites as an example of this problem the scholarship of eminent public finance economists Alan Auerbach and Laurence Kotlikoff, whose work in tax policy and tax-transition policy fields is, truly, "in many ways path breaking" ( $p$ 173). According to Shaviro, Auerbach and Kotlikoff define a consumption tax as "a wage tax plus a onetime

39 As Shaviro acknowledges, this example is taken from Kaplow. See also Kaplow, 99 Harv L Rev at 613 (cited in note 3). 
wealth tax upon its introduction" (p 173). Shaviro then rightly observes that this wealth tax really derives from an accounting change not a policy change, and he suggests further (again rightly) that understanding of the issues would be enhanced if such a wealth tax were not "built into" (or, made to seem an essential part of) the definition of a consumption tax. Thus, Shaviro suggests that the policy change/accounting change distinction, if nothing else, should be kept in mind for the sake of conceptual clarity and rigor. ${ }^{41}$

In addition, however, Shaviro wants to make a somewhat bolder use of his policy change/accounting change idea. He wants to argue that, just as retroactivity can produce only undesirable anticipatory behavior in the paradigm cases of accounting changes, making consumption-tax-related accounting changes retroactive can likewise only be a bad idea. Ergo, the implication is that the onetime wealth tax in the Auerbach and Kotlikoff consumption tax proposal (and in many other such proposals) is a bad idea. In one sense, a onetime wealth tax (whenever it is imposed) has obvious similarities to the accountingyear change mentioned above: taxpayers who happen to be wealthy at the time of the Auerbach and Kotlikoff transition get hammered; whereas, those whose wealth will be accumulated primarily after the transition enjoy a windfall gain. That distinction seems pretty arbitrary.

In another sense, however, a onetime tax on all wealth existing at the time of the shift to a consumption tax looks somewhat less arbitrary than the failure to provide transition relief in the accountingyear situation. That is, a onetime tax on wealth could conceivably be structured so as to be roughly consistent with our notions of distributive justice or progressivity. ${ }^{42}$ The same could not as easily be said about the tax that would be produced by a retroactive shift from an annual to a fiscal accounting year. Moreover, if taxpayers could be convinced that this tax truly is a onetime-only thing (just as the dramatic shift from an income to a consumption tax could plausibly be sold as a onetime-only move), it might have the optimal-tax benefits discussed in Part I.D above. That possibility, of course, provides a plausible justification for Auerbach and Kotlikoff's approach of link-

40 Alan J. Auerbach and Laurence J. Kotlikoff, Dynamic Fiscal Policy 57-59 (Cambridge 1987).

41 The example of an accounting change wealth tax that Shaviro most often refers to as being "built into" consumption-tax proposals, and the one that gets the most attention in the literature, is the onetime elimination of basis ("the tax system's record of outlays that qualify for eventual cost recovery but have not yet been deducted") upon the adoption of the consumption $\operatorname{tax}(p 10)$. As Shaviro points out, a basis "wipeout" could be done entirely within the income tax system and without a shift to a consumption tax (pp 10,184).

42 Especially if accompanied by a shift to a more steeply progressive wage tax, to improve progressivity with respect to post-transition wealth accumulation. 
ing the wealth tax to the shift to a consumption tax. As we have seen, however, these arguments do not fly with Shaviro. He just does not believe that such surprise retroactive taxes can work, even if "hidden" in the form of an ostensibly (though not actually) necessary element of a massive "one time" tax policy change.

\section{SHAVIRO'S PRIMARY INNOVATIONS: INTRODUCING POLITICAL REALITY AND TAX POLICY EXPERT OPINION}

\section{A. Attacking the Benevolent-Government Assumption}

Recall from Part I.C the assumption, which underlies the new view incentives analysis, that the long run path of government decisionmaking is upward, towards the overall improvement of social welfare. Not that every rule change has to be for the better; there will be mistakes and corrections and even mistaken corrections. But the general trend will be in the right direction. There will be progress. Thus, at its core, the new view is optimistic about the capacity of individuals, collectively through their government, to identify the common good and to achieve it. ${ }^{\text {*3 }}$

Shaviro rains on this parade. Drawing on an influential branch of political science, he summarizes three "core defects of public political choice that discourage adopting optimistic new view assumptions about government decisions" ( $p$ 66). These defects, which he terms the problems of aggregation, organization, and information, are well known. The problem of aggregation includes various voting paradoxes (including Arrow's theorem and the cycling phenomenon) that call into question the possibility of aggregating individual preferences in a coherent way. The problem of organization includes interest group theory, which sees government as a means of transferring wealth from the disorganized many to the well organized few. And the problem of information simply recognizes that decisions tend to be worse when made in ignorance and that, for all sorts of reasons (including defects one and two), many public political decisions are made in ignorance ( $\mathrm{pp}$ 67-73). Given these defects in the political decisionmaking pro-

43 Again, as I suggested above, Shaviro may be right about that conclusion, but whether he is depends on the merits of his anti-surprise-tax arguments (discussed in Part II.A), and not on the accounting change/policy change distinction.

44 It is important to note that, although Kaplow, Graetz, and some of the other architects of the existing economic/welfarist framework have used the above-stated benevolent-government assumption in their analyses, those scholars are by no means unaware of the sort of political concerns that Shaviro makes the focus of his book. For one example, in Kaplow's article, there is a long section on what he terms "institutional considerations," which include many of the public choice sort of concerns that Shaviro raises. See Kaplow, 99 Harv L Rev at 566-76 (cited in note 3 ). In addition, Levmore's article on retroactive taxation is, at its core, a public choice take on the surprise-retroactive-tax question. Still, Shaviro's book represents the most thorough study to date of the implications of public choice theory for a wide variety of transition issues. 
cess, "the mere fact of a policy change's adoption does not provide strong evidence of whether it [and therefore the incentive effect of making it retroactive] is good or bad" (p 73).

What follows from this observation? What is its implication for the choice of a welfare-maximizing transitions policy? Shaviro admits that, in the abstract, the answer is unclear. It is only in particular applications that the "policy payoff" will come (p 81). Most of Shaviro's book is devoted to working out the implications of these defects in the tax lawmaking context.

\section{B. The Reality of the Tax Lawmaking Process: Worse than Sausage}

If you think the legislative process in general is screwed up, wait until you get a load of the tax lawmaking process. It is especially ugly, says Shaviro. In support of this claim, he asserts that "[f]or decades, there has been a widespread consensus among those who closely follow tax policy that the legislative process in this area is seriously flawed, even by the standards of collective political choice generally" (p 86). He then goes on to argue that the tax lawmaking process exhibits the problems of organization and information (mentioned above) to a substantially greater degree than do other types of lawmaking. Again, this assertion is supported by the widely held view that "tax politics tends to be dominated by interest groups that seek favors for themselves and that, through a norm of logrolling, almost never oppose favors for each other" (pp 86-87) (citations omitted).

It is not that Shaviro claims that tax lawmaking is unique in having these pathologies, only that it is one of several problem areas, one of the areas of "distributive" politics, that is plagued by "particularly destructive interest group influence" ( $p$ 87). Other examples of distributive politics that he mentions are tariff legislation and pork-barrel spending (id). Whether Shaviro is right that tax lawmaking is exceptional in this regard, or whether he is being unjustifiably tax-centric in his public choice critique of the legislative process, is a question that is beyond the scope of this Review. However, as will become clear below, Shaviro's tax-exceptionalism arguments are central to his reasoning and ultimately to his transition policy recommendations.

\section{The First Thing We Do, Let's Kill All the Tax Preferences}

Shaviro believes that the exceptional flaws in the tax policymaking process (that is, the chronic and severe problems of organization and information) have produced a divergence between the tax system that every tax policy expert worth his or her salt would recommend and the tax system we actually have. Again invoking "a widespread consensus among tax policy thinkers," Shaviro urges that "society 
would benefit from the use of a more comprehensive tax base ("CTB") of either the income tax or consumption tax genre" (p 93). $\mathrm{He}$ then explains why the choice between the two CTBs-income or consumption-turns out not to be a momentous decision (with everything coming down to the question whether or not to have tax burdens turn on a taxpayer's preference for current or future consumption). Rather, the important tax policy question is whether to allow divergences from whichever tax base is chosen, whether to allow the use of special tax preferences-credits, deductions, exclusions-that favor some same-period investments over others. And for died-in-the-wool CTBers such as Shaviro that question is a no brainer: the answer is a resounding no. Keep the tax laws clean of tax preference provisions, henceforth and forever.

Here's the rub: the actual income tax code happens to be (and has always been) loaded with tax preferences. That fact is, unsurprisingly, a source of vexation for CTBers. ${ }^{47}$ Again, the problem from Shaviro's perspective is that any reasonably well-organized interest group can, with a little perseverance, persuade Congress to enact that group's pet tax subsidy. After all, those who stand to lose from the enactment of such tax preferences-that is, the taxpayers in general-are unorganized and therefore "little heard" ( $p$ 87). What's more (and this will become important below), Shaviro argues that taxpayers, because of a manifestation of the endowment effect, do not seem to understand the equivalence of a dollar that the government spends directly and a dollar spent indirectly via tax revenues forgone because of some special "tax expenditure" provision (pp 87-88). The result is that, although the general good would be served by the adoption of a clean, comprehensive, tax-subsidy-free income or consumption tax (or, put differently, by the wholesale and permanent repeal of all existing tax preference provisions), we just never seem to get there.

And here is where Shaviro's tax exceptionalism argument should be emphasized again: he does not contend that Congress should never intervene in the economy to encourage one type of investment over another. Indeed, he expressly rejects that conclusion. But he is clearly arguing that Congress should not, for the reasons just stated, intervene through the tax system to encourage one type of investment over another. The conclusion of this reasoning presumably is that Shaviro

45 Although he postpones "for another day" a full-fledged defense of the consensus view of the CTB idea, Shaviro clearly agrees with it and expressly adopts it for the purpose of his tax transitions analysis ( $p$ 94).

46 "Within the present income tax, the CTB norm suggests that tax preferences and dispreferences that discriminate between alternative forms of same-period consumption or investment are generally undesirable" (p 98).

47 One might even say a source of "sour grapes" ( $p 86)$. 
should favor any transition policy or practice that makes any tax preference less attractive to taxpayers. As I will suggest below, however, Shaviro seems to pull back from this conclusion at the last minute, for reasons about which I can only speculate.

The next several steps in Shaviro's analysis are devilishly clever and exceptionally (almost exceedingly) subtle. In effect, Shaviro sets out to design a tax transition policy that will maximize the beneficial effects of shifts in the direction of the CTB norm and minimize the harmful effects of movements in the other direction. ${ }^{43}$ In other words, he argues for a transition policy that will let the air out of tax preferences once and for all, even though (and, in some sense, especially because) Congress really likes using tax preferences. Therefore, in one sense, Shaviro wants to develop a constitutional tax transition norm that would ratify the current consensus among tax policy experts about what our tax code should look like, despite Congress's apparent disagreement with that consensus. Obviously, Shaviro has set no small task for himself.

He then starts out by making clear what his first-best tax transition policy would be. Recall that under Shaviro's framework, with respect to the type of rule change that we are now discussing-a policy change as contrasted with an accounting change-the choice of the optimal transition norm depends on the desirability of the new rule itself. $^{49}$ Thus, a decision that the CTB norm is the best steady-state tax policy has important implications, in theory, for the choice of an optimal tax transitions policy. Specifically, Shaviro's analysis to this point would suggest that the first-best constitutional tax transition norm would hold as follows: policy changes that represent movements in the direction of the CTB ideal (for example, any curtailment, including repeal, of a tax preference provision) will be made retroactive; whereas, any policy changes that move away from the CTB ideal (for - example, the enactment or expansion of such provisions) will not. In other words, transition relief should be provided in the latter cases, but not in the former ( $\mathrm{p} 99)$. $^{50}$

As Shaviro concludes, however, such a transition policy would be politically unrealistic. Consider the general message that such a norm would send to lawmakers: if you (Congresspersons) decide to enact a good change in the tax law (say, repealing a pesky tax preference), please make that change retroactive. That is precisely the sort of

48 In keeping with the subtlety and balance exhibited throughout the book, in the applications of this approach to specific cases, Shaviro notes that the CTB norm "does not provide the correct answer all the time" ( $p 132)$.

49 See note 38 and accompanying text.

50 Again, any accounting changes, in his view, should never be made retroactive, for the reasons already discussed in Part II.B. 
change that we (CTBers) would like to see taxpayers trying to anticipate. But if you decide to enact a bad rule change (for example, if you enact, against our advice, yet another tax preference), well, make that change apply prospectively only, to minimize the harm done.

Such a transition norm, Shaviro recognizes, would be neither stable nor binding. Indeed, it would be entirely self-defeating. It is almost impossible to imagine that the legislative majority that voted to approve a new tax subsidy would take kindly to the idea of intentionally blunting the effect of its new rule, merely because it is seen as a bad idea in the eyes of the tax policy cognoscenti ( $p 99)^{\text {st }}$

\section{Offsetting the Transition Gain/Loss Asymmetry}

By acknowledging that his idealized tax transition norm is a nonstarter, however, Shaviro does not mean to abandon his hope of using tax transition policy to maximize the benefits of the CTB norm and minimize the harm caused by departures from it. It just means that he must take a more indirect route to achieving his goal. And here is the path he takes: first, he recognizes that he must either go with an old view approach (generally opposing retroactivity) or go with a new view approach (generally supporting retroactivity), even though he disagrees with key assumptions underlying both approaches. As a practical matter, he concludes, that is the best that can be done (pp 98110).

Therefore, the question becomes which approach-old view or new view-would do the most to further the CTB norm. And Shaviro answers that question by reference to an observation regarding what he sees as the existing tax transition norm, an observation that is as important to his eventual policy recommendations as is his embrace of the CTB norm itself: he argues that there is currently a bias in Congress's tax transition constitutional norm in favor of compensating transition losers (if the losses result from the repeal of a tax preference) and against taxing away or otherwise eliminating transition gains (if the gains result from the enacment of a tax preference) (pp 88-91).

s1 Kaplow, in justifying his benevolent-government assumption, noticed this peculiarity with the alternative of making transition policy turn on the steady-state merits of particular rule changes. See Kaplow, 99 Harv L Rev at 566-76 (cited in note 3).

52 See id.

53 Shaviro also discusses other types of tax rule changes, such as changes in marginal tax rates. Because rate changes are of ten used to alter the distributional consequences of the tax laws, the choice of a transition policy (effective dates and such) will turn on the same distribution-efficiency tradeoffs that motivate the rate change in the first place (p 120). See also Logue, 94 Mich L Rev at 1170 (cited in note 4); Kaplow, 99 Harv L Rev at 519 (cited in note 3); Graetz, $126 \mathrm{U} \mathrm{Pa} \mathrm{L} \mathrm{Rev} \mathrm{at} \mathrm{82-83} \mathrm{(cited} \mathrm{in} \mathrm{note} \mathrm{8).} \mathrm{The} \mathrm{same} \mathrm{can} \mathrm{be} \mathrm{said} \mathrm{of} \mathrm{changes} \mathrm{in} \mathrm{the} \mathrm{social} \mathrm{security}$ laws, the subject of Shaviro's chapter 10. 
How do we know this is so? Shaviro offers both theoretical and empirical support. On the theory side, he argues that interest group theory would strongly suggest such a conclusion (p 89). The intuition, which seems entirely plausible, is that the political forces that would likely arise to oppose the imposition of a specific, identifiable transition loss would tend to be stronger than forces that would oppose the allowance of a transition gain."

On the empirical side, he offers two types of evidence. First, he notes that everyone who writes about transition issues, including the academics, tends to focus on transition "relief" for transition losses, even though he or she may acknowledge the gain/loss symmetry of transition issues. ${ }^{\text {s. }}$ So there must be a bias. Second, and more important, he looks at actual congressional practice and provides a couple of examples that support his gain/loss asymmetry hypothesis. For one, he observes that the so-called "binding contract" grandfather rule tends to be applied only when rule changes are made to the taxpayers' detriment ( $\mathrm{p} 90$ ). ${ }^{\text {s6 }}$ Thus, it is applied when depreciation deductions are curtailed, but not when they are expanded (id). And, of course, "rifleshot" transition rules-which apply to only one or a few taxpayersare always used only to prevent transition losses, never to take away transition gains. Shaviro concludes that, although these two "asymmetric effective date rules represent a discrete practice of limited general significance, they arguably bespeak an important broader attitude" (id).

Whether Shaviro is right about the "general significance" of these two examples, I don't know. But for purposes of this Review, I will assume he is. Therefore, let us assume that, owing to flaws in the tax lawmaking process, the existing tax transition policy embodies a general bias in favor of compensating transition losses and against taxing transition gains. So what? The answer lies in the CTB norm again. From the perspective of a card-carrying CTBer such as Shaviro, a norm that calls for compensating those who suffer transition losses when a tax preference is repealed but that also allows transition gains for those who anticipate new tax preferences cuts in exactly the wrong direction. That is, the anticipatory incentive effects of such a transition policy could not be worse.

54 With tranisition losses, the costs are concentrated on a relatively small and identifiable group; whereas, with transition gains, the costs, in terms of lost productive efficiency, are spread over all taxpayers.

55 See, even I did it. I mentioned the gain/loss symmetry in the introduction and then focused on transition losses throughout most of this Review. Shaviro must be onto something.

56 This special grandfather rule holds that "property placed in service after a new provision's effective date will nonetheless be taxed under the provision that it replaced, so long as the taxpayer had a binding contract to construct or acquire the property by a specified date" ( $\mathrm{p} 90$ ). 
Imagine the message that norm sends to taxpayers: Thinking about where to invest your resources? Wondering whether to rely on those enticing tax preferences, given the possibility of their repeal? Don't worry. Go ahead and rely on them. Even if they are repealed, your reliance interest will be protected by special transition rules, so long as you have a binding contract dated prior to the rule change. What's more, and get this, if you can somehow predict what new tax preferences Congress will cook up next, go ahead and invest there too, because (thanks to this wonderful asymmetry in the way tax law changes are implemented) the new tax preference will be applied retroactively to your pretransition investment. You can't lose.

This message, in effect, produces a transition subsidy for tax preferences and against the CTB norm. Shaviro, therefore, wants to change the message, and he wants to do so by advocating a new tax transition norm, which he hopes will come to replace the existing, biased one. Given that his first-best transition norm is not politically practical, and given that the norm against taxation of transition gains is unlikely ever to change, Shaviro chooses the new view alternative (which encourages policy change retroactivity), although, again, not for new view reasons but for public choice reasons.

\section{E. A Problem for Public Choice Normative Scholarship}

What is especially strange about Shaviro's transition policy conclusion is how he expects to pitch his proposal to Congress. He recognizes that the "real reason for advocating this norm-that in practice it may reduce Congress's predilection, through its transition policy, to favor tax preference expansion over curtailment-might lack broad appeal when stated forthrightly" ( $p$ 101). That is an understatement. Such a transition norm would have about as much chance of wooing legislators as would his first-best transition policy (that is, make your good laws retroactive, but not your bad ones).

In response to this concern, Shaviro suggests the possibility of arguing for the new view norm he proposes using a new view ("Graetzean") justification rather than his own ("Shaviroesque"?). defense. That is, he suggests arguing dishonestly, or least not "forthrightly," using terms that "are likely to sound more pleasantly in Congressional ears" (id). This suggestion, which I assume he means to be taken seriously, puts in stark relief one of the difficulties presented by publicchoice-oriented normative scholarship: what is a public choice tax policy scholar to do, when the audience he is trying to influence, whom he is trying to get to adopt his recommendations, is composed of the same group of people that his own theories suggest are not collectively capable of pursuing the public interest? The lesson of Shaviro's analysis seems to be that, first, you figure out what the right policy is 
(taking everything into account, including public choice concerns) and then you find a non-public-choice argument (which you may not really believe) to sell your recommendation to the policymaker. As far as I am aware, this approach itseif is another innovation of Shaviro's book and perhaps the most important one, because it reveals the most extreme implications for scholars of normative public choice analysis, at least in the tax context.

\section{F. The Anti-Nominal-Retroactivity Norm}

In addition to concluding that transition relief should be provided for tax law "accounting changes" but not for tax law "policy changes," Shaviro seems to reach one other general conclusion regarding tax transition policy: that the existing constitutional norm discouraging "nominally retroactive" tax law changes should be retained. ${ }^{57}$ This conclusion is puzzling. Not because it is a bad idea; indeed, the antinominal-retroactivity ("ANR") norm strikes me as eminently sensible, at least when applied to certain types of tax incentive provisions, such as investment credits (for example, the research and development credit). Were it not for an implicit, but strong, ANR norm, our investment credit provisions would have little effect. ${ }^{\text {ss }}$

What is puzzling is Shaviro's endorsement of the ANR norm, at least with respect to tax preferences. Given his apparent view that tax preferences are generally bad, I would have expected him to go out on a limb and favor nominally retroactive repeal of such provisions-the same way that he seems to endorse nominal retroactivity with respect to new product bans or the efficient expansion of tort liability doctrine. But for reasons that remain a little mysterious, he pulls back from that conclusion.

At first, I thought the mystery was solved by Shaviro's statement that there was a well entrenched anti-nominal-retroactivity norm that simply had to be acknowledged and recognized as a "brute fact" of political life ( $p$ 109). That conclusion suggested no endorsement of the norm, just a begrudging acceptance of it. But then Shaviro goes on to offer a justification of the ANR norm, offering a rationale that is especially interesting: he defends the ANR norm as a means of limiting the potential reach of government opportunism and of enabling "Congress to be able to make credible binding commitments (and not

57 Again, the precise definition of the term "nominally retroactive" is hard to pin down. One plausible definition in the tax context is the application of a tax rule change to a prior year's tax return (or to income earned or expenses incurred prior to the rule change).

58 When it comes to nominally retroactive tax rate increases, however, I am inclined toward Levmore's position, which seems more open to the occasional use of retroactive rate increases on optimal-tax normative grounds, but which acknowledges the public choice impediments to such an approach. See Levmore, 22 J Legal Stud at 265 (cited in note 1). 
just by the cumbersome practice of executing contracts)" (id). Thus, Shaviro harkens back to his discussion of "transactional flexibility" and "flavors" of rules, discussed in Part I.C above, apparently adopting a position that is consistent with my anti-opportunism arguments against unfettered retroactivity.

How does all of this fit together? On one hand, Shaviro seems to oppose the use of tax preferences, of any sort, ever. That sentiment motivates his endorsement of the CTB norm and, ultimately, his new view approach to transition losses. On the other hand, he favors the existing ANR norm, which provides some ransition protection to those who invest in reliance on tax preferences. Perhaps the best way to reconcile these positions is simply to say that Shaviro is splitting the difference between two competing concerns. Although his main goal is to discourage the use of tax preferences, because of the public choice problem of the few exploiting the many, he also wants to make some concession to the opposite concern, the problem of the many exploiting the few. And the ANR norm balances those concerns, in an admittedly imprecise but arguably tolerable way (pp 108-10).

\section{CONCLUSION}

Let me conclude with a few words on the "widespread consensus among tax policy thinkers" ( $p$ 93) in favor of the CTB norm and against the use of tax preferences, since, as Shaviro's book makes clear, one's views on that consensus are important to the choice of an optimal tax transition policy. Much has been written on the CTB norm over the years, as staunch CTBers have called into question the use of "tax expenditures" ${ }^{\text {"s }}$ and anti-CTBers have questioned the coherence and validity of the CTB ideal. ${ }^{60}$ In my view, although the anti-CTBers have had the better of the debate, the public choice concerns that Shaviro raises give me pause. That is, if we can overcome the conceptual difficulty of distinguishing between tax "preferences," on the one hand, and "structural" elements of the tax base, on the other (which is the difficulty rightly emphasized by anti-CTBers), Shaviro's worry about interest group influence seems valid.

My primary concern, however, with the CTB norm as articulated by Shaviro and incorporated into his transition recommendations is

'59 For a general discussion, see Stanley S. Surrey, Federal Income Tax Reform: The Varied Approaches Necessary to Replace Tax Expenditures with Direct Governmental Assistance, 84 Harv L Rev 352 (1970); Stanley S. Surrey, Tax Incentives as a Device for Implementing Government Policy: A Comparison with Direct Government Expenditures, 83 Harv L Rev 705 (1970).

60 See Douglas A. Kahn and Jeffrey S. Lehman, Tax Expenditure Budgets: A Critical View, 54 Tax Notes 1661, 1661 (1992); Boris I. Bittker, Accounting for Federal "Tax Subsidies" in the National Budget, 22 Natl Tax J 244,247 (1969); Boris I. Bittker, $A$ “Comprehensive Tax Base” as a Goal of Income Tax Reform, 80 Harv L Rev 925,934 (1967). 
the tax-exceptionalism problem. This Review is not the place to pursue the issue at length, but I suspect that the public choice critique of tax preferences would apply with equal strength to any other type of governmental preference. Although Shaviro acknowledges that there are other areas of "distributional politics" besides the tax area, he does not seem to recognize that whenever Congress seeks to encourage investments of one type over another, whether through the tax laws or through direct expenditures, all the same interest group concerns arise.

His response is that tax preferences are structurally distinct from direct expenditures in certain respects. The most important one, in Shaviro's analysis, is the role of the endowment effect. As suggested above, in Shaviro's view, there is a heuristic bias that "induces people to draw an exaggerated distinction between money that is never paid in to the Treasury and money that is first paid in and then taken back out" ( $p$ 87). And that bias gives tax preferences "greater political appeal" than would the same subsidy in the form of a direct expenditure (id).

But even if that is so, the normative implication is unclear. For example, if policy experts were to conclude on substantive grounds that a given subsidy-a given preference for one kind of investment over another-would be welfare enhancing, perhaps structuring the proposal in the form of a tax preference (rather than as a direct expenditure) would be desirable, precisely because of the endowment effect, precisely because it would minimize taxpayer opposition and maximize the odds of getting the change adopted.

Granted, such use of a cognitive psychology/public choice argument is cynical. But that is the nature of such arguments, and I did not start it. Moreover, at least in this case, the policy experts could be forthright with policymakers (if not with taxpayers) about the reason for choosing the tax code as the location for the preference. Of course, if the word got back to taxpayers that a trick was being played on them, the endowment effect might be lost. But if the tax-preference endowment effect were so easily eliminated, then Shaviro's objection to tax preferences in the first place would lose a great deal of its force. In that case, we could simply start by explaining to taxpayers the equivalence of tax expenditures and direct expenditures and be done with it.

Does my anti-tax-exceptionalism argument imply that we should reject the CTB norm and Shaviro's public choice concerns about tax preferences? Of course not. Those concerns are valid. They provide ample reason to be skeptical of any tax preference (putting aside for now the difficulty of defining a tax preference). My point, however, is that such concerns also provide ample reason to be skeptical of any 
governmental preferences, which means the public choice problem could be a much larger one than Shaviro's tax exceptionalism suggests.

Having said all of this, I, for one, am not yet sufficiently skeptical of the legislative lawmaking process to endorse a transition policy that would undermine lawmakers' ability ever to use tax (or, taken to the

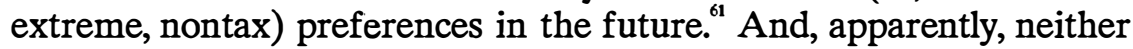
is Shaviro. Indeed, his bottom line transition proposal for tax preferences-including (critically) his endorsement of the ANR norm as applied to tax-preference repeals-strikes me as a sensible middle position. Under such a rule, although many types of tax preferences would be discouraged (because of the default-premium effect discussed in Part I.C above), if Congress nevertheless determines that a tax preference is called for, the use of various "up front" tax subsidies would continue to provide a default-premium-minimizing option for lawmakers.

Of course, from the perspective of the radical CTBer, the worry would be that, under Shaviro's proposal, the availability of transitionprotected up front tax subsidies is just another loophole that needs to be slammed shut. Fortunately, from the anti-opportunism perspective, the ANR norm appears to be safe, for now.

61 Part of my unwillingness to eliminate tax and nontax preferences from lawmakers' policy toolbox is that I still tend to hold a somewhat optimistic view of policymaking in the long run. For a similar sentiment, with respect to lawmaking generally, see Levmore, 99 Colum L Rev at 1662 (cited in note 11) ("In short, although there is an endless stream of pessimistic arguments about the likely character of laws, there may be a comparable-less familiar but perhaps superior-set of optimistic arguments supporting the idea that most new law is good law.").

62 "Up front" subsidies include credits or deductions all or most of whose benefits are concentrated in the first year of investment and thus for which an ANR norm provides almost full transition-loss protection. See Logue, 94 Mich L Rev at 1192-94 (cited in note 4); Kaplow, 99 Harv L Rev at 587 (cited in note 3). See also Daniel S. Goldberg, Tax Subsidies: Onetime vs. Periodic: An Economic Analysis of the Tax Policy Altematives, 49 Tax L Rev 305, 309-12 (1994). 


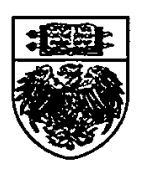

